\title{
Fission products and nuclear fuel behavior under severe accident conditions - Part 1: main lessons learnt from the first VERDON test
}

\author{
Y. Pontillon*, E. Geiger, C. Le Gall, S. Bernard, A. Gallais-During, P.P. Malgouyres, E. \\ Hanus and G. Ducros
}

CEA, DEN, CAD, DEC, F-13108 Saint-Paul-lez-Durance, France.

\begin{abstract}
One of the most important areas of research concerning severe accidents in PWR is certainly quantifying the source term of radioactive materials. This is in great part due to the consequences of the Three Mile Island (1979), Chernobyl (1986) and more recently Fukushima (2011) accidents.
\end{abstract}

A large number of research programs have thus been undertaken on this subject with particular efforts devoted to understanding the mechanisms that lead to the release of fission products (FP). In France, the HEVA-VERCORS programs, funded by IRSN and EdF, were initiated by the CEA and conducted up to 2002.

However, major uncertainties still remained. It has thus been decided to start a new co-operative research program, called "International Source Term Program (ISTP)", based on separate-effect experiments. Regarding the source term quantification, a new experimental device, VERDON, has been built in the LECA-STAR facility (CEA Cadarache site) and four VERDON tests are considered: Three of them are dedicated to the FP release from high burn-up $\mathrm{UO}_{2}$ fuel and from MOX fuel, one of them is dedicated to the impact of air ingress on the FP release from the fuel and their transport into the primary circuit.

The present paper describes the first VERDON test performed at the end of September 2011 with special emphasis on FP and actinides behavior during the accidental sequence itself (a second paper deals details the results regarding post-test examination (SEM, EPMA and SIMS) of the VERDON-1 sample). This test, devoted to $\mathrm{UO}_{2}$ fuel behavior and fission product releases under reducing conditions at very high temperature $\left(\sim 2610^{\circ} \mathrm{C}\right)$, has validated the very good performances of the VERDON loop. It did not result in a relocation of the fuel sample at 
the end of the test. According to the FP behavior measured by the on-line gamma station (fuel sight), the FP general classification, in relation to their released fraction, is very well highlighted together with the burn up effect on the release rate. 


\section{Introduction}

One of the most important areas of research concerning a severe accident in a pressurized water reactor (PWR), on both a French and an international level, is determining the source term, i.e. quantifying the nature, release rate and global released fraction of fission products (FP) and other radioactive materials. This is in great part due to the consequences of the Three Mile Island (1979), Chernobyl (1986) and more recently Fukushima accidents. In the course of this type of scenario, the chain of events can effectively result in primary coolant boiling and draining, meaning that it is no longer cooling the core. One direct result is the core melting and the release of FP and structural and/or activated control rod elements (e.g. activation products, AP) into the containment building. If there is a failure in the various protective barriers, the FP/AP can leak out of the containment building and be released into the environment.

A large number of research programs have thus been undertaken on this subject in various countries. In line with this approach, IRSN (France) has been the driving force and has conducted programs specifically focusing on determining the source term, with particular efforts devoted to understanding the mechanisms that lead to the release of FP, since only a very complete knowledge of the phenomena governing the behavior of FP/AP under such constraints will make it possible to define the actions that need to be planned (and/or performed) to minimize emissions and optimize the protection of both the people and the environment. The HEVA [1]/VERCORS [2] programs were thus initiated by the CEA. VERCORS has considerably broadened the field of application by exploring higher temperatures and by testing a wider range of fuels ( $\mathrm{UO}_{2}, \mathrm{MOX}$, debris bed configurations, high burn-ups) in a more complex experimental installation with better instrumentation. It was composed of 17 tests which were conducted over 14 years, in accordance with 3 experimental phases. A first series of six tests (VERCORS 1 to VERCORS 6, Table 1) conducted between 1989 and 1994 on $\mathrm{UO}_{2}$ fuel in a higher temperature range than the previous HEVA phase, close to the fuel relocation [3]. This series made it possible to integrate certain FP with low volatility into the HEVA results 
database. Two series of tests -VERCORS HT and RT (Table 2) - conducted alternately throughout 1996-2002 allowing the data base extension up to the less volatile FP.

These analytic experiments simulating severe PWR accidents were financed jointly by IRSN and EDF. Their aim was to quantify the released fraction and release rates of FP from irradiated nuclear ceramics $\left(\mathrm{UO}_{2}\right.$ or MOX, typically three PWR pellets in their original cladding), determine the nature of the gases and aerosols emitted (particle size analysis and speciation), and understand the fuel degradation mechanism. These experimental sequences were carried out in a very high activity cell and were commonly considered to be complementary to the PHEBUS FP [4] integral tests and comparable with certain tests carried out abroad: HI/VI [5] in the United States, VEGA [6] in Japan or the program conducted in Canada [7]. The experimental results of this program are used to (a) define the envelope values for released fraction within the scope of assessing reference source terms for all French PWRs, and (b) validate the semi-empirical or mechanistic models regarding FP release and transport while qualifying the simulation codes by integrating these models [8], [9], [10], [11].

However, major uncertainties still remained in some fields, concerning the assessment of risks for populations and the environment [12]. As a consequence, it has been decided to build a co-operative research program between teams involved in severe accident (SA) phenomenology all over the world (US-NRC, IRSN, CEA, EDF, PSI, European Commission, EACL, KAERI, ...), based on separate-effect experiments and called "International Source Term Program (ISTP)". The results of these separate-effect experiments would allow improving models used for Source Term evaluation studies. Four main R\&D research axes have been included in this program: (1) iodine study, (2) study of the boron carbide effect, (3) study of the air effect on fuel behavior and (4) study of the fission product release from the fuel.

As far as the source term quantification is concerned, four VERDON tests were considered. They are devoted to FP release from high burn up $\mathrm{UO}_{2}$ fuel, MOX fuels and air ingress scenario. They will be performed in the new VERDON laboratory at the CEA Cadarache center. 
The present paper deals with the VERDON-1 test itself. The main issue addressed by this first test concerns high burn up $\mathrm{UO}_{2}$ fuel behavior - and corresponding fission product releases -under reducing conditions at very high temperature (up to $2610^{\circ} \mathrm{C}$ ). Moreover, the first part of the test (i.e. up to the end of the so-called oxidation plateau at $1500^{\circ} \mathrm{C}$ ) is performed under the same atmosphere conditions compared to VERCORS RT6 test, which was conducted with a very similar $\mathrm{UO}_{2}$ high burn up fuel, in order to check the continuity between VERCORS and future VERDON data bases [1]-[3]. The second and third parts of this article [4], [5] deal in details with the results regarding post-test examination (SEM, EPMA and SIMS) of the VERDON-1 sample. The second part focuses on the fuel behavior during the VERDON-1 test and the third part describes a promising methodology to assess non $\gamma$-emitter FP release thanks to post-test characterizations.

In the first part of this paper, the experimental setup is described (section 2). In the second part (section 3), both the fuel sample and the progress of the accidental sequence are presented. In section 4, the results regarding FP release and fuel behavior are highlighted. The main results are discussed in the last part of the paper with a special focus on: (1) fuel relocation, (2) continuity between VERCORS and VERDON and (3) FP volatility and release kinetics.

\section{VERDON Experimental setup}

In the present part, the VERDON experimental circuit and the apparatus used to measure FP release / behavior are detailed successively.

\subsection{Experimental circuit}

The VERDON laboratory, implemented at the LECA-STAR facility, is constituted of 2 high activity cells (called C4 and C5) and a gloves-box, as illustrated in Figure 1. The C4 cell is dedicated to the sample reception, pre/post tests gamma scanning and loop elements storage. The C5 cell contains the experimental circuit itself (i.e. VERDON Loop). It is dedicated to the 
accidental sequence realization and to on-line measurements. The glove-box main functions are to analyze and store the fission and carrier gases. The VERDON Loop in its release configuration (as used for VERDON 1 test) is illustrated in Figure 2. This experimental loop is constituted of (along the path of gas flow): (1) The fluid injection system, (2) The furnace (see below), (3) An aerosol filter located directly on the top of the furnace. Its filtering part is constituted of stainless steel poral ${ }^{\circledR}$ which function is to stop all the fission products under aerosol form. The aerosol filter is heated at $175^{\circ} \mathrm{C} \pm 10 \%$, (4) A May-Pack filter, half part of this filter is filled with zeolite (impregnated with silver) in order to stop potential molecular iodine, the other part is empty and has been used as a gas gamma spectrometry sighting, even though the design and detector are not well suited; the May-Pack is heated at $150^{\circ} \mathrm{C} \pm 10 \%$ to avoid condensation, (5) A condenser whose function is to condense steam from the experimental gas and to recover the water for analysis, (6) A final safety filter which filtering part is constituted of stainless steel poral ${ }^{\circledR}$, in order to stop any residual trace of fission products (other than gaseous $\mathrm{Xe}, \mathrm{Kr}$ ), (7) Upstream from the condenser, the circuit is constituted of stainless steel tubes heated at $150^{\circ} \mathrm{C} \pm 10 \%$, (8) Downstream, the condenser is linked to the final safety filter thanks to a flexible stainless tube at ambient temperature, (9) Outside of the cell, a "linking line" is used to make the junction between the $\mathrm{C} 5$ cell and the gloves box. This gloves box is equipped with a flow-meter measuring the total flow-rate of the loop, a pressure sensor and a safety filter similar to the final safety filter of C5 cell (at the end of the release experimental loop). It is mainly dedicated to gas analysis and storage.

The VERDON furnace is based, as the previous VERCORS one, on induction technology [1]. Schematically (Figure 3), it is constituted of a coil surrounding a tungsten susceptor tube, which is the heating component of the furnace. A high frequency power supply generates a current in the coil. By electro-magnetic coupling, a current is generated into the susceptor tube and the corresponding electric energy is converted to thermal energy by Joule effect, leading to the heating of the susceptor tube. Then, the fuel sample, located inside the susceptor tube, is heated, mostly by thermal radiation. 
The external part of the furnace is constituted of a quartz tube sealed between 2 stainless steel bases thanks to 2 joints ${ }^{1}$. The internal part can be schematically divided into two areas delimited by a ceramic column. This latter is constituted by a double stack of concentric dense ceramics; in the central area, where the furnace temperature is the highest, the ceramics are in hafnium dioxide and at the ends, where the furnace temperature is the lower, they are in zirconium dioxide. The crucible, in which the fuel sample is introduced before the sequence, is located inside this ceramic column together with several cups allowing crucible's supporting and gases flow circulation. The susceptor and a double stack of concentric porous zirconia and hafnia are located outside of the ceramic column and are devoted to furnace insulation. A "susceptor gas" flow constituted of He circulates between the quartz tube and the "ceramic column" through the porous insulators and along both sides of the susceptor tube. It is maintained in slight overpressure regarding the experimental gas in order to create a protection of the susceptor tube (in tungsten) against oxidation from the experimental fluid.

In order to evaluate the fuel sample (center) temperature, a pyrometer, sighting under the crucible and 3 thermocouples (TC) located inside the insulators of the furnace are used. Two of these TC are in front of the fuel sample and the $3^{\text {rd }}$ is underneath (and used as a safety TC, in case the $1^{\text {st }}$ two ones were unusable). These TC are used to monitor the power supply of the furnace at low temperature, up to $1000^{\circ} \mathrm{C}$. At higher temperature, the $\mathrm{TC}$ give indicative values which can be used to check the consistency of the pyrometer measurement, since the pyrometer is used to monitor the power supply of the furnace at high temperature, from $1000^{\circ} \mathrm{C}$ up to $2610^{\circ} \mathrm{C}$.

\subsection{Fission Product measurements}

\footnotetext{
${ }^{1}$ The maximal temperature that these joints can sustain is about $300^{\circ} \mathrm{C}$ and for higher temperature, the tightness of the furnace would not be guaranteed. For this reason, these joints need to be adequately cooled by a dedicated cooling circuit located inside the bases, facing the joints
} 
In the case of VERDON-1 configuration, FP release kinetics was measured by means of three complementary on line gamma spectrometry stations and one micro gas chromatography apparatus:

1. One gamma station was aimed directly at the fuel sample and used during the entire test. This gamma station makes it possible to measure the FP remaining in the fuel as a function of temperature (presented in section 4.1), which explains why a relatively imprecise quantification of the release kinetics was obtained ${ }^{2}$. The two advantages of this station come (i) from its ability to measure directly at the source (all the FP were measured, unlike at the other stations where deposits upstream could occur) and (ii) for its ability to indicate the precise moment when the fuel relocates by detecting the disappearance (or significant decrease) in the signal from non-volatile FP. This last point was well illustrated in the case of the VERCORS series [2, 17]. This gamma station is also used in order to perform pre and post qualitative gamma scanning of the sample respectively before and after the accidental sequence (presented in section 4.2).

2. One other gamma station was aimed at the large-capacity aerosol filter. It provides a very precise measurement of the FP deposited at this point, where most of the volatile FP were found (presented in section 4.1). It is highly complementary with the previous station (fuel sight).

3. The last gamma station was aimed at the may-pack. The may-pack design has been performed in order to allow measuring potential iodine deposits (after test).

4. The gas analysis can be also performed on-line by a micro gas chromatograph ( $\mu \mathrm{GC})$ (or sequentially by 4 sampling aliquots) localized inside the gloves box. The $\mu$-GC extends the analysis of active gases to all the gases. Within the context of VERDON programs, the $\mu-\mathrm{GC}$ can analyze $\mathrm{H}_{2}$ (for concentration less than $1 \%$ ), $\mathrm{Kr}$ and $\mathrm{Xe}$.

In addition to the on-line gamma spectrometry measurements described above, which give access to FP release kinetics, the overall released fractions are obtained by means of quantitative gamma spectrometry of all the loop components. The measurements are carried out on a gamma

\footnotetext{
${ }^{2}$ At least $10 \%$ release have to be recorded by this station to guarantee a significate value, particularly as the changes in the object geometry measured during heating (swelling, fracturing, then fuel collapse, etc.) significantly complicate the quantitative use of the measurement, just like the axial migration of the FP.
} 
scanning bench located in the $\mathrm{C} 4$ high activity cell of the VERDON laboratory. The initial inventory (see section 3.1 for more details) of the FP was first of all established by scanning the fuel sample before the experimental sequence ${ }^{3}$ and was completed by calculations for the nongamma-emitting elements. Calculating the production of FP also allows (i) validating the coherence of the FP measurements and (ii) recalculating the irradiation conditions in PWR (fuel burn-up) and in the MTR (re-irradiation power level).

\section{Fuel sample characteristics and progress of the accidental sequence}

\subsection{VERDON-1 fuel sample characteristics}

The sample used was taken from $\mathrm{UO}_{2}$ fuel irradiated up to around $72 \mathrm{GWd.t} \mathrm{HM}^{-1}$ (6 cycles) in a PWR operated by EDF. The $\mathrm{UO}_{2}$ fuel pellets were manufactured by standard industrial process. The ${ }^{235} \mathrm{U}$ initial enrichment was $4.5 \%$. The sample was made up of a fuel rod section taken at the span 4 of the initial rod (FX0GAC-E04, irradiated 6 cycles in EdF Gravelines-5, Figure 4). It consists of two irradiated pellets in their original cladding (M5 alloy). Two half-pellets of depleted (and un-irradiated) uranium oxide are placed at each end of the sample and held there by crimping the cladding (Figure 4). Thus the cladding is not fully sealed. At this stage, it is important to note that the sample used in this test is very similar to the one involved in the VERCORS RT6 test (rod FX0GAC-N05 i.e. same fuel assembly, same power history, very closer burn up, Table 2).

Before the experimental sequence, the sample has been re-irradiated at low linear power in the OSIRIS material testing reactor for ten days, in order to recreate the short half-life FPs without any in-pile release. As a consequence, these FPs (i.e. ${ }^{99} \mathrm{Mo},{ }^{132} \mathrm{Te},{ }^{133} \mathrm{I},{ }^{131} \mathrm{I},{ }^{140} \mathrm{Ba} \ldots$ ),

\footnotetext{
${ }^{3}$ This initial inventory prior to the sequence is often determined in two stages: before the re-irradiation in the experimental reactor to precisely measure the FP with long half-lives, then just after this re-irradiation to measure the FP with short half-lives.
} 
important for their radiobiological effects, are measurable by using on-line gamma spectrometry during the experiment.

The initial FP inventory, which is used as reference to calculate the released fraction, is determined in two different ways, depending on the evaluated FP. The first way is to measure, by quantitative gamma spectrometry the contents of the VERDON-1 sample (before and after the re-irradiation in MTR). The second way is by calculating the FP content of the sample by a so-called evolution code like CESAR [13]. This was done because first, some fission products cannot be measured inside the pellet, ${ }^{85} \mathrm{Kr}$ for instance as well as all stable FP and/or pure $\beta$ emitters, but also in order to rescale the power history during both the base irradiation in PWR and MTR re-irradiation.

FP's initial inventories of the VERDON sample $\left(\mathrm{PWR} \mathrm{UO}_{2}\right)^{4}$ together with the Cesar 5.1 calculations are given in Table 3. From a general point of view, the consistency between calculated and experimental results are very good, excepted for ${ }^{125} \mathrm{Sb}$ and ${ }^{154} \mathrm{Eu}$ which are well known to be not correctly calculated by the Cesar code. The corresponding rescaling (to the average Measurement -gamma spectrometry over Calculated -Cesar code- (i.e. M/C) FP ratios) burn-up and power histories are respectively $72 \mathrm{GWd} . \mathrm{t}_{\mathrm{HM}}{ }^{-1}$ for PWR irradiation and $10 \mathrm{~W} . \mathrm{cm}^{-1}$ for MTR irradiation.

\subsection{VERDON Experimental Sequence}

The VERDON thermal-hydraulic sequence is illustrated in Figure 5. Three main different phases can be established according to the temperature and atmosphere (Table 4). Phase 1 and 2 are similar to VERCORS RT6, phase 3 is different (reducing for VERDON-1, oxidizing for RT6). Besides, one can note that there is a 1.5 hour troubleshooting resolution phase between phase 1 and phase 2. During this whole period, because of a technical problem, it was impossible to inject water, as it was initially defined, and consequently, to produce steam.

\footnotetext{
${ }^{4}$ A similar approach is performed for the un-irradiated half pellet, the corresponding measured amount is then included in the total FP initial inventory.
} 
But, as the troubles occurred at relatively low temperature (less than $1000^{\circ} \mathrm{C}$ ) the release of most of the FP had not begun and the impact of the temperature stabilization and slight decrease on FP release is negligible.

As explained above, some helium has been injected in the susceptor circuit (He Sus) during the whole sequence so that the over pressure between the experimental circuit and the susceptor circuit is maintained and the protection of the $\mathrm{W}$ susceptor tube regarding oxidation is guaranteed.

The criterion which is used to determine the end of the sequence is either to detect the fuel sample relocation or to reach the maximal temperature $\left(\mathrm{T}_{\max }=2610^{\circ} \mathrm{C}\right)$. As illustrated in Figure 6, at the end of the sequence $\left(1700^{\circ} \mathrm{C}<\mathrm{T}<2610^{\circ} \mathrm{C}\right)$, no significant ${ }^{140} \mathrm{La}$ signal decrease was recorded by the gamma station. The end of the accidental sequence (shut down of HF power supply) was performed when the maximal temperature of $2610^{\circ} \mathrm{C}$ was reached.

\section{$4 \quad$ FP release and fuel behavior}

\subsection{FP release}

In this part, the release kinetics, recorded by the fuel sight gamma station, is described according to the well-established FP classification (see discussion): non or low-volatile, volatile (including fission gases) and semi-volatile fission products.

The release kinetics shown in Figure 6a and Figure $\mathbf{6 b}$ illustrate that no significant release of $\mathrm{Zr}, \mathrm{La}, \mathrm{Eu}, \mathrm{Np}$ and $\mathrm{Ru}$ is measured at this stage. Besides, no global relocation of the fuel sample is recorded by this gamma station (i.e. no global loss of the signal is recorded up to the end of the test at $\left.2610^{\circ} \mathrm{C}\right)$.

There is a total release of the iodine and cesium species measured at the end of the test, with an equivalent behavior, in term of release rate, between these two elements (Figure 7). The released fraction obtained at the end of the oxidation plateau is very high (around 60\% of the initial inventory) with a start of release at $\sim 1200^{\circ} \mathrm{C}$. Beside, right before the beginning of release 
$\left(1000^{\circ} \mathrm{C}<\mathrm{T}<1200^{\circ} \mathrm{C}\right)$ a slight decrease of the "released fraction" of ${ }^{137} \mathrm{Cs}$ is detected (Figure 7).

This is due to a cesium's axial and longitudinal migration inside the fuel pellet ${ }^{5}$.

The fission gases release kinetics (Figure 8) are characterized by a series of burst releases. In each case, the amplitude is greater for $\mathrm{Xe}$ than for $\mathrm{Kr}$, in line with the expected $\mathrm{Xe} / \mathrm{Kr}$ ratio. The first burst release starts at around $700-800^{\circ} \mathrm{C}$ (about $4 \%$ of $\mathrm{Kr}$ and $6 \%$ of Xe). There is a second little burst release around $1000^{\circ} \mathrm{C}(\sim 2 \%$ both $)$. The following burst release starts at about $1100^{\circ} \mathrm{C}(16 \%$ of total $\mathrm{Kr}$ and $14 \%$ of total $\mathrm{Xe})$. The main burst release occurs during the oxidation plateau at $1500^{\circ} \mathrm{C}(43 \%$ of total $\mathrm{Kr}$ and $47 \%$ of total Xe). A series of low burst releases occurs from $1800^{\circ} \mathrm{C}$ to the end of heating ( $20 \%$ of total $\mathrm{Kr}$ and $21 \%$ of total Xe). The last puff ( $15 \%$ of total $\mathrm{Kr}$ and $10 \%$ of total $\mathrm{Xe}$ ) occurs at the beginning of the decrease of temperature. The fission gases release kinetics show a time lag between $\mathrm{Kr}$ and $\mathrm{Xe}$ at every burst end. This behavior can be a consequence of the zeolite contained in the May-Pack which yields to a separation of these two gases ${ }^{6}$. The $\mathrm{Kr}$ global release is slightly underestimated because of its limit of detection (about 1ppm), and its relative low concentration (compared to $\mathrm{Xe})$. The loss of $\mathrm{Kr}$ signal, calculated between first and last burst release does not exceed $4 \%$ of total $\mathrm{Kr}$ measured. The loss of signal of the last puff, due to the end of measurement, can be evaluated up to $7 \%$ of total $\mathrm{Xe}$ and $\mathrm{Kr}$ measured (symmetrical burst end). The last puff probably indicates the complete drainage of the residual intragranular inventory of fission gases.

Figure 9 presents the $\mathrm{Ba}$ and Mo release kinetics up to $1500^{\circ} \mathrm{C}$ in order to allow a direct comparison with the VERCORS RT6 test (see section 5, discussion). A start of Mo release during the beginning of the so-called oxidation plateau at $1500^{\circ} \mathrm{C}$ with a very strong rate release kinetics up to approximately $40 \%$ of the initial inventory at the two third of the plateau is monitored. More or less symmetrically as compared to that of molybdenum, the release of barium does not start during the $1500^{\circ} \mathrm{C}$ plateau. Only a slight decrease of the "released

\footnotetext{
${ }^{5}$ This FP axial and/or longitudinal migration inside the fuel pellet is seen as an over-concentration by the gamma station, resulting in an apparent decrease of the "released fraction" as it has been previously observed during the VERCORS programme
} 
fraction" of Ba is visible in Figure 9. This is probably due to barium axial and/or longitudinal migration inside the fuel pellet as it was observed in many VERCORS test (see section 2, [2]).

In order to illustrate the general behavior of the FP belonging to the four volatility categories, Figure 10 compares the release kinetics of Zr, Cs, I, Ba and Mo.

\subsection{FP global behavior}

Just before the loop dismantling and in order to get preliminary information on both FP release and FP final distribution inside the sample, the fuel sight gamma station is used as a longitudinal bench. The sample is then gamma scans inside the furnace. A comparison between the results obtained before and after the test is then performed according to a qualitative method (i.e. the efficiency is considered equal to 1 in both cases). Comparison of the FPs distributions along the sample before (blue curve) and after (pink curve) the VERDON-1 test, obtained by gamma scanning of the sample inside the furnace, is shown in Figure 11, Figure 12 and Figure $\mathbf{1 3}$ respectively for non or low-volatile $\left({ }^{95} \mathrm{Zr},{ }^{154} \mathrm{Eu},{ }^{103} \mathrm{Ru}\right)$, semi-volatile $\left({ }^{99} \mathrm{Mo}\right.$ and $\left.{ }^{140} \mathrm{Ba}\right)$ and volatile FPs $\left({ }^{137} \mathrm{Cs}\right.$ and $\left.{ }^{131} \mathrm{I}\right)$.

From a general point of view, the main information deduced from the on-line measurements (see section 4.1) is confirmed by the FP distribution along the sample:

No significant release is measured, at this stage (and with this approach), for the so-called non or low volatile FPs, excepted for Ru where some little deposits are observed just above the crucible,

$\checkmark$ No general degradation of the sample is highlighted by these post test gamma signals (i.e. for the non volatile FP), since the final shape of the sample (after the test) illustrated by the FP distribution, is more or less the same than that before the sequence,

\footnotetext{
6 This zeolite "pre-column" effect was previously seen on calibration gas $\mathrm{Kr}$ and $\mathrm{Xe}$ during commissioning tests before VERDON-1 but was not quantified
} 
Strong and quasi total release respectively for semi-volatile and volatile FPs, and stronger release of Ba compared to Mo are measured.

After these measurements, the sleeve is extracted from the furnace and gamma measured on the $\mathrm{C} 4$-gamma bench. The total gamma count as a function of the displacement along the sleeve is given in Figure 14. The corresponding FP location is pointed out on this distribution. They are very consistent with the previous results and the well-known class of FP volatility, with:

- no or very low deposits respectively for the non $(\mathrm{Zr}, \mathrm{Nd})$ or low volatile $(\mathrm{Nb}$, $\mathrm{Np}, \mathrm{Ru}) \mathrm{FP}$. In the latter case the deposits are in the high temperature part of the sleeve (i.e. just above the crucible).

- Semi volatile FP present lot of deposits all along the sleeve with a significant retention in the sample.

- Volatile FP (I, Cs, Te) present no or a very little retention into the sample with low deposits in the extreme upper part of the sleeve just before the filter entrance.

As previously measured, the non volatile FP distributions do not evidence any significant fuel collapse. In fact, the general shape of the VERDON sample is found: two half un-irradiated pellets and the two PWR fuel pellets. The major modification lies on a global swelling of the sample of about $20 \%$ in length.

Finally, as observed during the VERCORS program for the volatile FP:

- limited cesium retention inside the PWR fuel is measured

- Iodine is quasi only detected inside the un-irradiated half pellet.

Finally, as explained in above, all the loop elements are gamma scanned in order to perform the global FP balance. From a general point of view, one can note the very good consistency, in term of released fraction, obtained by the different methods (Figure 15): (1) differential between the measurement of the sample before and after the test (RF APS/AVS) and 
(2) the sum of the deposited fractions. This point is probably one of the most important information deduced for this first VERDON test. In fact, this confirms the very good behavior of the loop during this type of accidental sequence. Moreover, the released fractions obtained by the on-line gamma fuel sight are also very consistent with the previous values (Table 5).

\section{Discussion}

The VERDON-1 results, in term of FPs and fuel behavior, presented in the previous part of this paper may be discussed according to three main axes: (1) fuel behavior with special focus on relocation temperature, (2) comparison with VERCORS RT6 test and finally (3) general FP volatility.

\subsection{Fuel relocation}

For the so-called "VERCORS HT and RT" series, the experimental facility had been totally refurbished with two complementary test loop configurations: the complex HT configuration [14] (three tests), integrating the additional aim of studying FP transport in the primary system of a PWR and their potential interaction with the elements composing the neutron absorbers of a PWR (Ag, In, Cd and B, [15]), and the compact RT configuration (eight tests), more specifically focused on the release of low volatile FP and transuranium elements. All these tests were conducted by bringing the fuel sample up to fuel relocation to quantify the entire volatility range of FP [2]. Figure 16 displays fuel collapse temperatures as a function of different selected VERCORS tests. Systematic fuel collapse has been detected for a temperature range of $2100-2350^{\circ} \mathrm{C}$ whatever the burn up from $47 \mathrm{GWd}^{-\mathrm{HM}^{-1}}{ }^{-1}$ to $70 \mathrm{GWd} \cdot \mathrm{t}_{\mathrm{HM}}{ }^{-1}$; thus there is no great effect of the high burn up. Besides, whatever the test atmosphere conditions, the temperature at which the fuel loses its integrity is systematically inferior to both the melting point of un-irradiated $\mathrm{UO}_{2}$ and the solidus temperature of the $\mathrm{ZrO}_{2}-\mathrm{UO}_{2}$ eutectic [16]. Moreover, fuel collapse temperature seems to decrease in oxidizing conditions. This point is 
well highlighted by HT1, HT2 and HT3 tests which were performed on the same fuel section in reducing conditions for HT1 and HT3 and oxidizing conditions for HT2. The corresponding fuel collapse temperatures are approximately $\sim 2300^{\circ} \mathrm{C}$ for $\mathrm{HT} 1$ and $\mathrm{HT} 3$ and $\sim 2000^{\circ} \mathrm{C}$ for $\mathrm{HT} 2$. This general behavior has been already discussed in details elsewhere [17], [18]. According to these data analysis in the $\mathrm{UO}_{2+\mathrm{x}}$ composition domain, a new thermodynamic modelling of $\mathrm{U}-\mathrm{O}$ phase diagram has been defined. An important consequence of this new optimization is that a liquid phase may appear in the $\mathrm{O}-\mathrm{UO}_{2}-\mathrm{ZrO}_{2}$ composition domain of the $\mathrm{U}-\mathrm{O}-\mathrm{Zr}$ phase diagram at $2330^{\circ} \mathrm{C}$ at atmospheric pressure (this temperature decreasing with increase of pressure, about $2230^{\circ} \mathrm{C}$ at 2 atm.). These temperatures can be associated with the temperature at which the fuel assembly could lose its integrity in oxidizing conditions and then with what was observed in some of the VERCORS tests (and quite differently from reducing test conditions) or in the PHEBUS tests.

VERDON-1 test does not result in a global and/or strong relocation of the fuel sample at the end of the test (i.e. up to a temperature of $2610^{\circ} \mathrm{C}$ ). This behavior may be connected, by analogy to the previous explanation, to the final atmosphere of the test (i.e. reducing conditions). However, the temperature "reaches" by the VERDON-1 sample is certainly one of the main points of the test, and at this stage, the exact origin of this behavior needs to be clearly demonstrated and more investigated [4].

\subsection{Comparison with RT6}

As explained in introduction, the first part of the VERDON-1 test (i.e. up to the end of the oxidation plateau at $1500^{\circ} \mathrm{C}$ ) was performed under the same atmosphere conditions compared to VERCORS RT6 test, and was conducted on a very similar $\mathrm{UO}_{2}$ high burn up fuel, in order to check the continuity between VERCORS and the future VERDON data bases. In order to perform these analyses, Figure 9a and Figure 9b compare the release kinetics respectively for the semi volatile and volatile fission products during VERCORS RT6 and VERDON-1 tests. If one looks at the middle of the oxidation plateau, in both cases the general FP behavior (release rate and kinetics) are very similar. For $\mathrm{Ba}$ and Mo the releases reach 
respectively approximately $0 \%$ and $40-45 \%$ in the two experiments. For volatile species, around $60 \%$ are obtained in the two considered experiments. These latter points are very important since they highlighted a perfect continuity between the two facilities in term of FP release [19].

\subsection{FP volatility}

From a general point of view, analysis of the released fractions obtained during all the VERCORS program [2] made it possible to classify the FP into four categories of decreasing volatility: Volatile FP (including fission gases, iodine, cesium, antimony, tellurium, cadmium, rubidium and silver), Semi-volatile FP such as molybdenum, rhodium, barium, palladium and technetium, Low volatile FP such as ruthenium, niobium, strontium, yttrium, lanthanum, cerium and europium and finally $\underline{\text { Non-volatile FP }}$ include zirconium, neodymium and praseodymium $^{7}$.

The released fraction obtained thanks to the data analysis presented in this paper are in good agreement with the VERCORS results and with what we can expect regarding FP behavior in VERDON-1 thermal-hydraulic condition (i.e. reducing/neutral at high temperature). In more details, following information may be highlighted thanks to a general comparison with the VERCORS data base and in line with the above FP classification.

For all the VERCORS tests performed at temperature representative of a severe accident, the fission gas release was complete. The instantaneous fission gas (FG) release kinetics were characterized by successive burst releases at each temperature ramp. Besides, a higher release of long half-life $\mathrm{FP}\left({ }^{85} \mathrm{Kr}\right)$ at low temperature (below $1200-1300^{\circ} \mathrm{C}$ ) is monitored, due to the higher gas content inventory located at the grain boundaries for this type of gas [20], compared to short half-life FP $\left({ }^{133} \mathrm{Xe},{ }^{135} \mathrm{Xe}\right)[21]$, as well as the final puff linked to the fuel melting and inducing the release of the ultimate gas fraction contained in the intragranular

\footnotetext{
${ }^{7}$ It was shown that actinides can be subdivided into two categories. The first includes $\mathrm{U}$ and $\mathrm{Np}$ with released fraction that can reach $10 \%$, with a behavior similar to the low-volatile category; the second $(\mathrm{Pu})$ has very low released fraction, typically considerably less than $1 \%$, with a behavior more-like non volatile FP
} 
bubbles. Between these two phenomena, fission gas release is driven by intragranular diffusion. Results obtained for VERDON-1 are in perfect line with these observations. Beside, even though no general fuel collapse has been obtained, a very last puff is recorded at the end of the sequence where a complete release is measured.

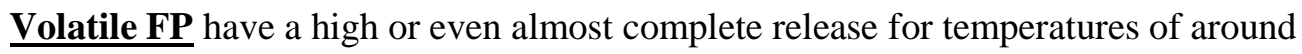
$2330^{\circ} \mathrm{C}$. The nature of the test (fuel type, initial geometry, atmosphere at the end of the test, etc.) essentially affects the release kinetics of these species and has little effect on the released fraction once this temperature level has been attained during the test. $\underline{\mathbf{I} \text { and } \mathbf{C s}}$ release rate are somewhat equivalent. There was a total release for iodine and almost total release for cesium in all the most severe VERCORS tests. In fact, it has been measured that a low but significant amount of cesium remained present in the sample for various tests, with released fractions of around $97-98 \%$. Cesium retention in the corium was also identified as a result of the TMI2 accident, where associations with oxides stable at high temperatures were proposed: metal oxides of chromium $\left(\mathrm{Cs}_{2} \mathrm{Cr}_{2} \mathrm{O}_{4}\right)$ or iron $\left(\mathrm{Cs}_{2} \mathrm{Fe}_{2} \mathrm{O}_{4}\right)$, or silicates $\left(\mathrm{Cs}_{2} \mathrm{Si}_{4} \mathrm{O}_{9}\right)$ [22]. Apart the complete release of these FP, the strong fuel burn-up impact on release kinetics has been also highlighted. In order to illustrate this point, Figure 17 shows a comparison between the release kinetics of cesium during RT1 (considered as RT's reference test) and RT6 (high burn-up test). The ${ }^{137}$ Cs release kinetics during RT6 is much faster than for RT1, conducted in similar atmospheric conditions; for instance, at the end of the "oxidation plateau" $\left(1500^{\circ} \mathrm{C}\right)$, the fraction of cesium released is approximately three times higher for RT6 and, throughout the test, the corresponding fractional release is at every moment greater. A similar increase of the release kinetics was observed for (1) MOX fuel, compared to $\mathrm{UO}_{2}$ fuel, (2) "debris bed" configurations, compared to rod-like geometry, as well as for (3) oxidizing atmosphere instead of reducing. Again the VERDON-1 results are very similar, with small retention of cesium inside the sample $(<0.5 \%)$ and a faster release kinetics compared to a fuel with a moderate burn-up. For instance, the release was approximately of $60 \%$ at the beginning of the $1500^{\circ} \mathrm{C}$ plateau in VERDON-1 to be compared to around $20 \%$ at the same moment for VERCORS RT1 (4 cycles $\mathrm{UO}_{2}$ fuel,

Figure 17). Generally speaking, tellurium and antimony release are comparable and quasi 
total for all of the most severe VERCORS sequences. The main difference is in terms of quantities deposited in the hot zones of the experimental loop: much higher for antimony than tellurium. For VERDON-1, Sb and Te releases are respectively $76 \%$ and $96 \%$ with deposited fractions of $\sim 50 \%$ and $32 \%$ (in the same order) along the sleeve. These results are in good agreement as far as the deposited fraction along the sleeve is concerned and also for the total release of Te. On the opposite, the released fraction of Sb is small. In fact, it has been noted that the $\mathrm{Sb}$ releases were lower for the RT grid tests (80-95\%) compared to the VERCORS 3, 4 and 5 tests (97-100\%). This behavior has been attributed to antimony retention in the corium formed after fuel relocation. Since VERDON-1 is characterized by a high temperature without fuel collapse, a stronger release should be expected. However, this point may be also due to an experimental artefact linked to the low detection, by gamma spectrometry, which characterizes these two FP. If it is the case, the released fractions obtained at this stage would correspond to the minimum of release. In other words, the "real" release would be higher. According to this line, if the detection limit calculated during the data treatment of the crucible zone is taken into account as a real FP detection for $\mathrm{Sb}$ (125 and 127 isotopes), an amount of around 5 to $10 \%$ in the crucible should be deduced from this approach, which would correspond to a global release (deduced from APS/AVS by the classical differential method) of 90-95\%.

The behavior of the semi-volatile FP is characterized by releases that can be very high, in some cases as much as those of volatile FP, i.e. near total release, but with high sensitivity to the oxygen potential, and giving rise to significant deposits on the sleeve located above the fuel sample. The Mo release is enhanced in oxidizing conditions, on the opposite Ba release is enhanced in reducing conditions. Moreover, release kinetics seems to be faster for high burn up fuel. In fact, the results obtained for VERCORS RT6 show a significant increase in the fractional release compared to VERCORS 4 and 5 (Figure 18); for instance, at $\mathrm{T}=2000^{\circ} \mathrm{C}, 40 \%$ and $100 \%$ for Ba and Mo respectively for VERCORS RT6 instead of 0\%(0\%) and 10\% (70$80 \%$ ) for VERCORS 4 (and 5). VERDON-1 results confirm these observations with a very fast and high Mo release in the first part of the test (oxidizing $\mathrm{H}_{2} \mathrm{O} / \mathrm{H}_{2}$ atmosphere conditions). In the same time no Ba release is measured. On the other hand, during the second part of the test 
(reducing conditions), the release of Mo stops and the Ba release becomes very fast. After the sequence no drastic differences are measured with a slightly higher release of Ba compared to Mo ( $\sim 65 \%$ and $\sim 70 \%$ respectively for Mo and Ba) with deposits along the sleeve of $\sim 19 \%$ (Mo) and $24 \%(\mathrm{Ba})$ of the initial inventory, which correspond to approximately $30-35 \%$ of the total release.

Low volatile FP have low, yet significant, released fraction of around $3 \%$ to $10 \%$ on average, but these values can attain $20-40 \%$ in the case of some FP under particular conditions, e.g. oxygen potential or high burn-up. In addition, the FP in this category are essentially deposited in the high temperature section of the test loop, i.e. close to the fuel. At this stage of the data analysis, the VERDON-1 results are also very consistent with these observations since no significant release has been measured by the fuel sight gamma station which is known to have a low sensibility which allows monitoring precisely release superior than $10 \%$ [3] of the initial inventory.

$\underline{\mathrm{Zr}}$ and Nd do not have produced any detectable release during VERDON-1, as it has been the case for all the VERCORS tests.

\section{Conclusion}

This paper deals with the VERDON-1 test. The main issue addressed by this first test concerns high burn up $\mathrm{UO}_{2}$ fuel behavior - and corresponding fission product releases -under reducing conditions at very high temperature (up to $2600^{\circ} \mathrm{C}$ ). Moreover, the first part of the test (i.e. up to the end of the oxidation plateau at $1500^{\circ} \mathrm{C}$ ) has been performed under the same atmosphere conditions compared to VERCORS RT6 test, which was conducted with a very similar $\mathrm{UO}_{2}$ high burn up fuel, in order to check the continuity between VERCORS and the future VERDON's data bases. This experiment has been performed in the new VERDON laboratory built at the Cadarache CEA center.

During this VERDON-1 test, the good performances of the VERDON loop in terms of tightness, thermal-hydraulics, hafnia ceramics behavior, etc.... and of the gamma scanning and sighting have been clearly demonstrated. As a consequence it can be now asserted that the VERDON facility is technology-approved. 
The results, in term of FP and fuel behavior, presented in the previous part have been discussed according to three main axes: (1) relocation temperature, (2) comparison with VERCORS RT6 test and finally (3) general FPs volatility.

Generally speaking, the VERDON-1 test does not result in a global and/or strong relocation of the fuel sample at the end of the test (i.e. up to a temperature of $2610^{\circ} \mathrm{C}$ ). This behavior must be connected to the final atmosphere of the test (i.e. reducing conditions).

The comparison with VERCORS RT6 has been possible and conclusive. Similar FP release kinetics at $1500^{\circ} \mathrm{C}$, high burn up effect on release kinetics and atmosphere effect on $\mathrm{Mo}, \mathrm{Ba}$ release are measured. The VERDON loop is thus qualified in "release configuration", and

\section{VERDON is in continuity with VERCORS experiments.}

According to the released fractions measured by on-line gamma station and thanks to the information obtained via pre and post test gamma scanning, the FP general classification, in relation to their released fractions and specific behavior, is again obtained with: (1) volatile FP (fission gases, iodine, cesium, tellurium, antimony) with an almost total release; (2) semivolatile FP (molybdenum and barium), with high sensitivity to oxidizing-reducing conditions and significant released fractions; (3) FP that are low or no volatile (ruthenium, europium, niobium, cerium, zirconium, neodymium).

[1] Leveque et al., 1994. The HEVA experimental programme. Nucl. Technol. 108, 33-44

[2] Y. Pontillon, G. Ducros, P.P. Malgouyres, Nucl. Eng. Des. 240 (2010) 1843-1852 ; Y. Pontillon, G. Ducrosn Nucl. Eng. Des. 240 (2010) 1853-1866 ; Y. Pontillon, G. Ducros Nucl. Eng. Des. 240 (2010) $1867-1881$

[3] Ducros et al., 2001. "Fission Product release under severe accidental conditions; general presentation of the program and synthesis of VERCORS 1 to 6 results". Nucl. Eng. Des. 208, 191-203

[4] Schwarz et al., 1999. PHEBUS FP: a severe accident research programme for current and advanced light water reactors. Nucl. Eng. Des. 187, 47-69

[5] Lorenz R.A., Osborne M.F., 1995. A summary of ORNL fission product release tests with recommended release rates and diffusion coefficients. Report ORNL/TM-12801 - Nureg/CR-6261

[6] Kudo T., Hidaka A., Fuketa T., 2005. VEGA; an experimental study of radionuclides release from fuel under severe accident conditions. In: proceedings of Water Reactor Fuel Performance meeting 2005, Kyoto, Japan ; Hidaka et al., Journal of Nuclear Science and Technology, vol. 48, (2011), 85

[7] Lui Z. et al., 1994. A summary of CRL fission product release measurements from UO2 samples during post-irradiation annealing (1983-1992). Report COG-92-377

[8] Veshchunov, et al., 2003. "Development of the mechanistic code MFPR for modelling fission product release from irradiated UO2 fuel (part 1). Development and validation of new models". In: Proceedings of ENS Topfuel 2003, Würzburg, Germany

[9] Dubourg, R., Nicaise, G., 2003. "Development of the mechanistic code MFPR formodelling fission product release from irradiated UO2 fuel (part 2). Application to integral tests VERCORS 4-5 and PHEBUS FPTO". In: Proceedings of ENS Topfuel 2003, Würzburg, Germany 
[10] Brillant G., Marchetto C., Plumecocq W., 2010. "Ruhtenium release from fuel in accident conditions", Radiochim. Acta, 98(5), p.267-275, 2010

[11] Beuzet E. et al., 2012. "Ruthenium release modelling in air and steam atmospheres under severe accident conditions using the MAAP4 code", Nucl. Eng. Des. 246 (2012) 157-162

[12] CLEMENT, B., The Phebus Fission Product and Source Term International Programs, Int. Conf. Nuclear Energy for New Europe 2005 Bled, Slovenia, September 5-8, 2005

[13] Cesar5.1, developed by DEN/DER/SPRC, CEA-Cadarache

[14] P.P. Malgouyres, G. Ducros, M.P. Ferroud-Plattet, M. Prouve, D. Boulaud, "The VERCORS HT facility for studies up to molten fuel conditions", European working group "hot laboratories and remote handling" meeting, Windscale, (1998).

[15] Y. Pontillon, G. Ducros, P.P. Malgouyres, C. Fiche, M. Kissane, D. Boulaus, J.M. Evrard, "Fission product release and transport in severe-accident conditions: comparison between VERCORS HT1/HT2/HT3 experiments concerning $\mathrm{UO}_{2}$ fuel in reducing and oxidizing conditions with and without control rod components", Cooperative Severe Accident Research Program meeting, Bethesda, Maryland, USA, may 2003

[16] (a) C. Guéneau, M. Baichi, D. Labroche, C. Chatillon, B. Sundman, J. Nuc. Mater., 304, 161-175, (2002), (b) M. Baichi, Doctoral Thesis, Institut National Polytechnique de Grenoble, September, 2001.

[17] Pontillon, Y., et al., 2005. Study of the active role played byUO2-ZrO2-PF interactions on irradiated fuel collapse temperature from VERCORS tests. J. Nucl. Mater. 344, 265.

[18] M. Barrachin et al., New modelling of the $\mathrm{U}-\mathrm{O}-\mathrm{Zr}$ phase diagram in the hyper-stoichiometric region and consequences for the fuel rod liquefaction in oxidising conditions, Journal of Nuclear Materials, Volume 375, 2008, 397

[19] A. Gallais-During, J. BONNIN, P.P. MALGOUYRES, S. BERNARD, Y. PONTILLON, E. HANUS, G. DUCROS, "VERDON Laboratory : Performances of the Experimental LWR Severe Accident Device and First Results of Fission Products Release on High Burn-up UO2 Fuel", 21st International Conference Nuclear Energy for New Europe, Ljubljana, slovenia, September 2012

[20] Noirot J., et al. "Fission Gas Inventory in PWR high burnup fuel: Experimental Characterisation and Modelling", Proc. of The 2004 Water Reactor Fuel Performance Meeting, September 19-24, 2004, Orlando, Floride, USA

[21] Y.Pontillon, D. Parrat, M.P. Ferroud Plattet, S. Ravel, G. Ducros, C. Struzik, A. Harrer, Fisson Gas Release From High Burn-up $\mathrm{UO}_{2}$ Fuels Under Simulated Out-of-Pile LOCA Conditions, IAEA TECHNICAL MEETING ON IMPROVED FUEL PELLET MATERIALS AND DESIGN, 20-24 October, 2003, Brussels, Belgium

[22 ] Hobbins, R.R., et al., 1993. "Fission product release from fuel under severe accident conditions". Nucl. Technol. 101, 270 


\section{Figure Captions.}

Figure 1. Schematic view of the VERDON laboratory

Figure 2. The so-called release experimental loop

Figure 3. The VERDON furnace

Figure 4. Location of the fuel rod section used for the VERDON-1 sample

Figure 5. VERDON Experimental sequence

Figure 6. Low or non volatile FP release kinetics, (a) ${ }^{154} \mathrm{Eu},{ }^{95} \mathrm{Zr}$ and ${ }^{140} \mathrm{La},(\mathrm{b}){ }^{103} \mathrm{Ru},{ }^{97} \mathrm{Zr}$ and ${ }^{238} \mathrm{~Np}$

Figure 7. Volatile FP (I, Cs) release kinetics

Figure 8. Fission gas release kinetics

Figure 9. Release kinetics comparisons between VERCORS RT6 and VERDON-1: (a) volatile FPs, (b) semi-volatile FPs

Figure 10. Release kinetics of $\mathrm{Zr}$, I, Cs, Ba, Mo during the whole VERDON-1 test.

Figure 11. Gamma scanning of the sample inside the VERDON furnace $\left({ }^{95} \mathrm{Zr},{ }^{154} \mathrm{Eu},{ }^{103} \mathrm{Ru}\right)$ before (in blue) and after (in pink) the test.

Figure 12. Gamma scanning of the sample inside the VERDON furnace $\left({ }^{99} \mathrm{Mo}\right.$ and $\left.{ }^{140} \mathrm{Ba}\right)$ before (in blue) and after (in pink) the test.

Figure 13. Gamma scanning of the sample inside the VERDON furnace $\left({ }^{137} \mathrm{Cs}\right.$ and $\left.{ }^{131} \mathrm{I}\right)$ before (in blue) and after (in pink) the test.

Figure 14. Total gamma count rate along the VERDON-1 sleeve

Figure 15. Comparison between the released fractions deduced from the sample analysis (RF APS/AVS) and by the sum on the loop elements 
Figure 16. Fuel collapse temperature for several VERCORS tests and VERDON-1 compared to the melting point of non- irradiated $\mathrm{UO}_{2}$ (i.e. $2869^{\circ} \mathrm{C}$ from [16])

Figure 17. Release rate of ${ }^{137} \mathrm{Cs}$ as a function of temperature: Comparison between RT1 (reference test) and RT6 (high burn-up fuel)

Figure 18. Release rate of ${ }^{99} \mathrm{Mo}{ }^{\text {and }{ }^{140}} \mathrm{Ba}$ as a function of temperature: Comparison between RT6 and VERCORS 4 and 5 
Table 1. VERCORS 1 to 6 test matrix parameters

\begin{tabular}{|c|c|c|c|c|c|c|}
\hline Test & VERCORS 1 & VERCORS 2 & VERCORS 3 & VERCORS 4 & VERCORS 5 & VERCORS 6 \\
\hline Date of test & $11-1989$ & $06-1990$ & 04-1992 & $06-1993$ & $11-1993$ & 06-1994 \\
\hline \multicolumn{7}{|l|}{ Fuel } \\
\hline PWR irradiation & Fessenheim & Bugey & Bugey & Bugey & Bugey & Gravelines \\
\hline Fuel burn-up (GWd/tU) & 42,9 & 38,3 & 38,3 & 38,3 & 38,3 & 60 \\
\hline Re-irradiation & Siloe & Siloe & Siloe & Siloe & Siloe & Siloe \\
\hline \multicolumn{7}{|l|}{ Test conditions } \\
\hline Max fuel temperature $(\mathrm{K})$ & 2130 & 2150 & 2570 & 2570 & 2570 & 2620 \\
\hline Atmosphere (end of test) & Mixed $\mathrm{H}_{2} \mathrm{O}+\mathrm{H}_{2}$ & Mixed $\mathrm{H}_{2} \mathrm{O}+\mathrm{H}_{2}$ & Mixed $\mathrm{H}_{2} \mathrm{O}+\mathrm{H}_{2}$ & Hydrogen & Steam & Mixed $\mathrm{H}_{2} \mathrm{O}+\mathrm{H}_{2}$ \\
\hline Last plateau duration (min) & 17 & 13 & 15 & 30 & 30 & 30 \\
\hline Steam flow rate $(\mathrm{g} / \mathrm{min})$ & 0,15 & 1,5 & 1,5 & $1,5-0$ & 1,5 & 1,5 \\
\hline Hydrogen flowrate (g/min) & 0,003 & 0,027 & 0,03 & 0,012 & 0 & 0,03 \\
\hline
\end{tabular}


Table 2. VERCORS HT-RT test matrix parameters

\begin{tabular}{|c|c|c|c|c|c|c|c|c|c|c|c|}
\hline VERCORS tests & HT 1 & HT 3 & HT 2 & RT 1 & RT 2 & RT 5 & RT 4 & RT 3 & RT 7 & RT 6 & RT 8 \\
\hline Date of test & June 1996 & June 2001 & April 2002 & March 1998 & April 1998 & $\begin{array}{c}\text { December } \\
1998\end{array}$ & June 1999 & $\begin{array}{c}\text { November } \\
1999\end{array}$ & April 2000 & \begin{tabular}{|c} 
September \\
2002
\end{tabular} & $\begin{array}{c}\text { November } \\
2002\end{array}$ \\
\hline Fuel & $\mathrm{UO}_{2}$ & $\mathrm{UO}_{2}$ & & & MOX & & $\begin{array}{l}\mathrm{UO}_{2} / \mathrm{ZrO}_{2} \\
\text { debris bed }\end{array}$ & $\begin{array}{l}\mathrm{UO}_{2} \text { debris } \\
\text { bed }\end{array}$ & & & \\
\hline $\begin{array}{l}\text { Burnup (GWd/tu } \\
\text { Re-irradiation }\end{array}$ & $\begin{array}{c}47 \\
\text { SILOE }\end{array}$ & $\begin{array}{c}\sim 47 \\
\text { OSIRIS }\end{array}$ & $\begin{array}{c}\sim 47 \\
\text { OSIRIS }\end{array}$ & $\begin{array}{l}47 \\
\text { No }\end{array}$ & $\begin{array}{l}41 \\
\text { No }\end{array}$ & $\begin{array}{c}60 \\
\text { OSIRIS }\end{array}$ & $\begin{array}{c}3 \text { cycles } \\
\text { No }\end{array}$ & $\begin{array}{l}3 \text { cycles } \\
\text { OSIRIS }\end{array}$ & $\begin{array}{l}3 \text { cycles } \\
\text { OSIRIS }\end{array}$ & $\begin{array}{l}6 \text { cycles } \\
\text { OSIRIS }\end{array}$ & $\begin{array}{l}6 \text { cycles } \\
\text { OSIRIS }\end{array}$ \\
\hline $\begin{array}{l}\text { Max fuel } \\
\text { temperature (K) } \\
\text { / Fuel collapse }\end{array}$ & $2900 / 2500$ & $2750 / 2500$ & $2600 / 2300$ & 2570 & 2440 & $\begin{array}{l}\text { Fuel } \\
\text { collapse }\end{array}$ & $\begin{array}{l}\text { Fuel } \\
\text { collapse }\end{array}$ & Fuel melting & $\begin{array}{l}\text { Fuel } \\
\text { melting }\end{array}$ & Fuel melting & $\begin{array}{l}\text { Fuel } \\
\text { melting }\end{array}$ \\
\hline $\begin{array}{l}\mathrm{H}_{2}(\mathrm{mg} / \mathrm{s}) \\
\mathrm{H}_{2} \mathrm{O}(\mathrm{mg} / \mathrm{s}) \\
\text { Air }(\mathrm{mg} / \mathrm{s})\end{array}$ & $\begin{array}{c}0,2 \\
0 \\
0 \\
\end{array}$ & $\begin{array}{c}0,2 \\
0 \\
0 \\
\end{array}$ & $\begin{array}{c}0 \\
25 \\
0 \\
\end{array}$ & $\begin{array}{c}0,45 \\
25 \\
0 \\
\end{array}$ & $\begin{array}{c}0,45 \\
25 \\
0 \\
\end{array}$ & $\begin{array}{c}0,45 \\
25 \\
0 \\
\end{array}$ & $\begin{array}{c}0,4 \\
14,6 \\
0 \\
\end{array}$ & $\begin{array}{c}1,25 \\
1,25 \\
0 \\
\end{array}$ & $\begin{array}{c}0,2 \\
0 \\
0 \\
\end{array}$ & $\begin{array}{c}0,45 \\
25 \\
0 \\
\end{array}$ & $\begin{array}{c}0 \\
0 \\
0,8 \\
\end{array}$ \\
\hline Main objective & $\begin{array}{c}\mathrm{H}_{2} \text { atm., high } \\
\text { temperature, } \\
\text { HT } \\
\text { reference } \\
\text { test }\end{array}$ & $\begin{array}{l}\text { Boric acid } \\
\text { and SIC } \\
\text { injection }\end{array}$ & $\begin{array}{l}\text { Boric acid } \\
\text { and SIC } \\
\text { injection }\end{array}$ & $\mid \begin{array}{c}\text { RT reference } \\
\text { test }\end{array}$ & MOX fuel & $\begin{array}{l}\text { High } \\
\text { Burnup }\end{array}$ & $\begin{array}{l}\text { Phebus } \\
\text { FPT4 } \\
\text { support }\end{array}$ & $\begin{array}{c}\text { Fuel } \\
\text { volatilization }\end{array}$ & MOX fuel & $\begin{array}{c}\text { High burn up } \\
\text { fuel }\end{array}$ & $\begin{array}{c}\text { High burn } \\
\text { up fuel / } \\
\text { air } \\
\text { injection }\end{array}$ \\
\hline
\end{tabular}


Table 3 : FP's initial inventory of the VERDON 1 sample, comparison between gamma spectrometry measurements and Cesar 5.1 calculations, with $(\mathrm{M} / \mathrm{C}) 1$ and $(\mathrm{M} / \mathrm{C}) 2$ respectively for OSIRIS and PWR power history.

\begin{tabular}{|c|c|c|c|c|c|}
\hline \multirow[b]{2}{*}{ FP } & \multirow[b]{2}{*}{ Half-life } & \multicolumn{4}{|c|}{ UO2 PWR } \\
\hline & & Measurements & Calculations & $\begin{array}{c}\text { Calculation }^{*}(\mathrm{M} / \mathrm{C}) \\
(\mathrm{M} / \mathrm{C}) 1,(\mathrm{M} / \mathrm{C}) 2\end{array}$ & $M / C$ \\
\hline Zr95 & $63.98 \mathrm{~d}$ & $3,54 \mathrm{E}+16$ & $3,39 E+16$ & $3,60 \mathrm{E}+16$ & 0,98 \\
\hline Nb95 & $65,00 \mathrm{~d}$ & 1,77E+15 & $1,58 E+15$ & $1,68 E+15$ & 1,06 \\
\hline Mo99 & $2,75 \mathrm{~d}$ & $1,81 E+16$ & $1,67 E+16$ & $1,77 E+16$ & 1,02 \\
\hline Ru103 & $39,3 d$ & $3,96 E+16$ & $3,89 E+16$ & $4,13 \mathrm{E}+16$ & 0,96 \\
\hline Ru106 & $1,017 y$ & $3,83 \mathrm{E}+16$ & $3,65 E+16$ & $3,80 E+16$ & 1,01 \\
\hline Sb125 & $2,76 y$ & $3,95 \mathrm{E}+16$ & $1,03 \mathrm{E}+17$ & $1,07 E+17$ & 0,37 \\
\hline Sb127 & $3,85 d$ & $1,19 E+15$ & $1,35 E+15$ & $1,43 E+15$ & 0,83 \\
\hline Te132 & $78,20 \mathrm{~h}$ & $1,58 \mathrm{E}+16$ & $1,47 \mathrm{E}+16$ & $1,56 \mathrm{E}+16$ & 1,01 \\
\hline 1131 & $8,02 \mathrm{~d}$ & $1,76 E+16$ & $1,64 E+16$ & $1,74 E+16$ & 1,01 \\
\hline$T 133$ & $20,80 \mathrm{~h}$ & $7,13 E+15$ & $6,57 E+15$ & $6,97 E+15$ & 1,02 \\
\hline Cs134 & $2,07 y$ & $5,49 E+17$ & $5,32 \mathrm{E}+17$ & $5,54 \mathrm{E}+17$ & 0,99 \\
\hline Cs137 & $30,17 y$ & $1,16 E+20$ & $1,11 E+20$ & $1,16 E+20$ & 1,00 \\
\hline Ba140 & $12,8 \mathrm{~d}$ & $3,30 \mathrm{E}+16$ & $3,08 \mathrm{E}+16$ & $3,27 E+16$ & 1,01 \\
\hline La140 & $1,68 d$ & $4,54 E+15$ & $4,03 E+15$ & $4,28 E+15$ & 1,06 \\
\hline$\overline{C e 141}$ & $32,50 \mathrm{~d}$ & $3,74 E+16$ & $3,36 E+16$ & $3,57 E+16$ & 1,05 \\
\hline Ce143 & $33,00 \mathrm{~h}$ & $8,00 E+15$ & $7,32 \mathrm{E}+15$ & $7,77 \mathrm{E}+15$ & 1,03 \\
\hline Nd147 & $11,00 d$ & $1,08 E+16$ & $1,16 E+16$ & $1,23 E+16$ & 0,87 \\
\hline Eu154 & $8,80 y$ & $1,14 \mathrm{E}+18$ & $2,37 E+18$ & $2,47 E+18$ & 0,46 \\
\hline Eu156 & $15,19 \mathrm{~d}$ & $3,13 E+15$ & $2,86 E+15$ & $3,04 E+15$ & 1,03 \\
\hline Np238 & $2,12 \mathrm{~d}$ & $6,61 E+15$ & $5,91 E+15$ & $6,27 E+15$ & 1,05 \\
\hline
\end{tabular}


Table 4. VERDON-1 temperature and atmosphere

\begin{tabular}{|c|c|c|}
\hline & temperature & atmosphere \\
\hline Phase 1 & $\begin{array}{l}\text { Ambient to } 400^{\circ} \mathrm{C}\left(0.1^{\circ} \mathrm{C} / \mathrm{s}\right) \\
\text { Plateau at } 400^{\circ} \mathrm{C}: 1 \mathrm{~h}\end{array}$ & $\begin{array}{l}\text { Neutral: } \\
\text { He Sus }=2 \mathrm{mg} / \mathrm{s} \\
\text { He Exp }=4 \mathrm{mg} / \mathrm{s}\end{array}$ \\
\hline $\begin{array}{l}\text { Troubleshooting } \\
\text { resolution phase }\end{array}$ & $\begin{array}{l}400^{\circ} \mathrm{C} \text { to } 775^{\circ} \mathrm{C} \\
\text { Stabilization at } 775^{\circ} \mathrm{C} \\
\text { Down to } 650^{\circ} \mathrm{C} \text { (HF power supply } \\
\text { shut down) } \\
\text { Stabilization at } 775^{\circ} \mathrm{C} \\
\text { Total duration } \sim 1.5 \mathrm{~h}\end{array}$ & $\begin{array}{l}\text { Reducing } \\
\mathrm{H} 2 \mathrm{O}=0 \mathrm{mg} / \mathrm{s} \\
\mathrm{H} 2=0.45 \mathrm{mg} / \mathrm{s} \text { and } 0 \mathrm{mg} / \mathrm{s} \\
\text { when HF power supply shut } \\
\text { down } \\
\text { He Sus }=5 \mathrm{mg} / \mathrm{s}\end{array}$ \\
\hline Phase 2 & $\begin{array}{l}775^{\circ} \mathrm{C} \text { to } 1500^{\circ} \mathrm{C}\left(0.2^{\circ} \mathrm{C} / \mathrm{s}\right) \\
\text { Plateau at } 1500^{\circ} \mathrm{C}: 50 \mathrm{~min}\end{array}$ & $\begin{array}{l}\text { Oxidizing } \\
\mathrm{H} 2 \mathrm{O}=25 \mathrm{mg} / \mathrm{s} \\
\mathrm{H} 2=0.45 \mathrm{mg} / \mathrm{s} \\
\mathrm{He} \text { Sus }=5 \mathrm{mg} / \mathrm{s}\end{array}$ \\
\hline Phase 3 & $\begin{array}{l}1500^{\circ} \mathrm{C} \text { to } 2000^{\circ} \mathrm{C}\left(0.2^{\circ} \mathrm{C} / \mathrm{s}\right) \\
\text { Plateaus every } 100^{\circ} \mathrm{C}: 10 \mathrm{~min} \\
\text { until } 2200^{\circ} \mathrm{C} \\
\text { Plateaus every } 100^{\circ} \mathrm{C}: 5 \mathrm{~min} \\
\text { until } 2400^{\circ} \mathrm{C}\end{array}$ & $\begin{array}{l}\text { Reducing: } \\
\text { molar ration H2/H2O = } 10 \\
\mathrm{H} 2 \mathrm{O}=0.3 \mathrm{mg} / \mathrm{s} \\
\mathrm{H} 2=0.33 \mathrm{mg} / \mathrm{s} \\
\mathrm{He} \text { Sus }=5 \mathrm{mg} / \mathrm{s} \\
\mathrm{He} \text { Exp }=6 \mathrm{mg} / \mathrm{s}\end{array}$ \\
\hline Phase 3b & $2400^{\circ} \mathrm{C}$ to $2611^{\circ} \mathrm{C}\left(0.2^{\circ} \mathrm{C} / \mathrm{s}\right)$ & $\begin{array}{l}\text { Neutral } \\
\mathrm{H} 2 \mathrm{O}=0 \mathrm{mg} / \mathrm{s} \\
\mathrm{H} 2=0 \mathrm{mg} / \mathrm{s} \\
\mathrm{He} \text { Sus }=5 \mathrm{mg} / \mathrm{s} \\
\mathrm{He} \text { Exp }=6 \mathrm{mg} / \mathrm{s}\end{array}$ \\
\hline
\end{tabular}


Table 5 : Comparison between released fractions obtained by the differential approach (before versus after test) and by on-line gamma fuel sight

\begin{tabular}{|c|c|c|}
\hline FP & $\begin{array}{c}\text { RF (APS/AVS) } \\
\text { crucible }\end{array}$ & $\begin{array}{c}\text { RF fuel sight } \\
\text { Kinetics }\end{array}$ \\
\hline Kr85 & $100,0 \%$ & ND \\
\hline Zr95 & $0,3 \%$ & $0,0 \%$ \\
\hline Nb95 & $0,0 \%$ & $<5-10 \%$ \\
\hline Zr97 & $0,9 \%$ & $0,0 \%$ \\
\hline Mo99 & $63,7 \%$ & $60,0 \%$ \\
\hline Ru103 & $1,3 \%$ & $0,0 \%$ \\
\hline Sb125 & & $\mathrm{ND}$ \\
\hline Sb127 & & $61 \%$ à $2120^{\circ} \mathrm{C}$ \\
\hline Te132 & $95,0 \%$ & $67 \%$ à $1670{ }^{\circ} \mathrm{C}$ \\
\hline I131 & $93,7 \%$ & $100,0 \%$ \\
\hline I133 & $\mathrm{ND}$ & $100,0 \%$ \\
\hline XE133 & $100,0 \%$ & $\mathrm{ND}$ \\
\hline Cs134 & $99,9 \%$ & $100,0 \%$ \\
\hline Cs137 & $99,4 \%$ & $100,0 \%$ \\
\hline Ba140 & $76,4 \%$ & $\sim 75 \%$ \\
\hline La140 & $0,0 \%$ & $0,0 \%$ \\
\hline Ce143 & $0,2 \%$ & $0,0 \%$ \\
\hline Nd147 & $0,0 \%$ & $0,0 \%$ \\
\hline Eu154 & $-1,1 \%$ & $0,0 \%$ \\
\hline Np238 & $2,8 \%$ & $0,0 \%$ \\
\hline Np239 & $2,1 \%$ & $0,0 \%$ \\
\hline
\end{tabular}

